\title{
PENERAPAN METODE TOPSIS UNTUK PENGANGKATAN KARYAWAN KONTRAK MENJADI KARYAWAN TETAP (STUDI KASUS: PT HANURABA SAWIT KENCANA)
}

\author{
Catur E Gunawan \\ Prodi Sistem Informasi, UIN Raden Fatah Palembang \\ Email: caturerig@ radenfatah.ac.id
}

(Naskah masuk: 19 Maret 2020, diterima untuk diterbitkan: 25 Maret 2020)

\begin{abstract}
Abstrak
PT Hanuraba Sawit Kencana merupakan perusahaan yang bergerak di bidang perkebunan kelapa sawit yang berada di Desa Manggar Jaya Kecamatan Tanjung Lago Kabupaten Banyuasin, Sumatera Selatan. Kegiatan utama perusahaan ini meliputi pengelolaan kebun inti dan plasma berikut Pabrik Minyak Sawit (PMS), dengan produk utama minyak sawit dan inti sawit. Permasalahan yang dihadapi oleh pihak perusahaan PT Hanuraba Sawit Kencana dalam menentukan pengangkatan karyawan kontrak menjadi karyawan tetap yaitu sulitnya dalam proses penilaian yang objektif terhadap calon karyawan tetap. Penelitian ini bertujuan untuk melakukan penerapan metode TOPSIS untuk pengangkatan karyawan kontrak menjadi karyawan tetap. Metode yang digunakan dalam penelitian ini yaitu metode TOPSIS. Metode ini digunakan karena mempertimbangkan solusi ideal positif dan solusi ideal negatif. Dengan kata lain di setiap atribut pada kriterianya akan dipilih nilai terbaik untuk mendefinisikan nilai pada solusi ideal positif, dan sebaliknya di setiap atribut pada kriterianya juga akan dipilih nilai terburuk untuk mendefinisikan nilai pada solusi ideal negatif. Kemudian pada akhirnya akan membandingkan nilai pada solusi ideal positif dan nilai pada solusi ideal negatif. Penilaian ini diharapkan dapat membantu menghasilkan rekomendasi yang bersifat objektif. Dari penelitian ini, hasil yang didapatkan nilai Kedekatan Relatif (Relative Closeness) yang tertinggi yaitu 0.97. Seluruh daftar alternatif terbaik ini akan menjadi rekomendasi bagi perusahaan. Dengan melakukan penelitian ini diharapkan dapat mempermudah pihak perusahaan dalam proses seleksi karyawan kontrak menjadi karyawan tetap dengan penilaian yang objektif sesuai dengan kriteria-kriteria penilaian yang telah ditetapkan oleh pihak perusahaan dan kriteria tambahan dari penelitian ini.
\end{abstract}

Kata kunci: Karyawan Kontrak, Karyawan tetap, Metode TOPSIS

\section{THE APPOINTING A CONTRACT EMPLOYEE TO A PERMANENT EMPLOYEE USING TOPSIS METHOD (CASE STUDY: PT HANURABA SAWIT KENCANA)}

\begin{abstract}
PT. Hanuraba Sawit Kencana is a company engaged in the field of oil palm plantations located in Manggar Jaya Village, Tanjung Lago District, Banyuasin Regency, South Sumatera. The company's main activities include the management of nucleus and plasma plantations and Palm Oil Mill (POM), with the main products being palm oil and palm kernel. The problems faced by the company PT Hanuraba Sawit Kencana in determining the appointment of a contract employees to become permanent employees, namely the difficulty in the process of an objective assessment of prospective permanent employees. The method used in this study is the TOPSIS method. In other words, in each attribute on the criteria will be chosen the best value to define the value of a positive ideal solution, and then in each attribute on the criteria will also be selected the worst value to define the value of the negative ideal solution. Finally, will compare the value of a positive ideal solution and the value of a negative ideal solution. This assessment is expected to help produce objective recommendations. From this study, the highest value of Relative Closeness is 0.97. The whole list of the best alternatives will be a recommendation for the company. By conducting this study, it is expected to facilitate the company in the process of selecting a contract employees to become permanent employees with an objective assessment in accordance with the assessment criteria set by the company and additional criteria of this study.
\end{abstract}

Keywords: A Contract Employee, A Permanent Employee, TOPSIS Method 


\section{PENDAHULUAN}

Kemajuan teknologi telah mengalami perkembangan yang sangat pesat, berbagai perkantoran termasuk yang bergerak di bidang Perkebunan, Keuangan, Pendidikan, dan Pemerintahan sangat membutuhkan teknologi dalam aktivitas mereka untuk mendukung pekerjaannya. Pemanfaatan teknologi salah satu fungsinya yaitu untuk membantu dalam mengambil keputusan yang biasanya dilakukan oleh seorang pimpinan perusahaan. Sistem informasi yang banyak digunakan untuk membantu seorang pimpinan suatu perusahaan dalam pengambilan keputusan biasa disebut dengan Sistem Pendukung Keputusan (SPK). SPK merupakan sistem informasi yang berisi informasi, pemodelan dari metode yang digunakan, dan pemanipulasian data yang dapat digunakan untuk pengambilan keputusan semiterstruktur dan tidak terstruktur[1].

Pembuatan sistem pendukung keputusan tentunya menggunakan berbagai macam metode yang ada. Penerapan metode pendukung keputusan ini bertujuan untuk dapat memudahkan proses pengambilan keputusan. Selain itu para pimpinan bisa mendapatkan keputusan yang sifatnya objektif. Keputusan yang bersifat objektif biasanya adil karena sesuai dengan fakta-fakta dan didukung oleh datadata untuk menghasilkan suatu keputusan/ rekomendasi keputusan yang bisa memudahkan para pimpinan perusahaan atau organisasi. Menurut Pratiwi, menjelaskan tiga (3) jenis keputusan yang bisa dibedakan menjadi, yaitu: 1) keputusan terstruktur; 2) keputusan tak terstruktur; dan 3) keputusan semi terstruktur. Keputusan terstruktur lebih mengarah pada permasalahan yang sifatnya rutin dan berulang. Biasanya pada keputusan terstruktur sudah dibuatkan standar untuk menyelesaikan permasalahan tersebut. Selanjutnya, pada keputusan tak terstruktur lebih bersifat samarsamar, bahkan belum ada standar untuk menghasilkan solusi yang baik untuk menyelesaikan permasalahan tersebut. Terakhir, pada keputusan semi terstruktur peraturan-peraturan yang dibuat belum sepenuhnya lengkap. Sehingga solusi yang dihasilkan masih bersifat subjektif[2].

Dikarenakan untuk menghasilkan keputusan yang sifatnya objektif dibutuhkan sebagai solusi yang adil, oleh karena itu metode pendukung keputusan dapat dimanfaatkan di organisasi atau perusahaan. Salah satu bidang perusahaan yang dapat memanfaatkan metode pendukung keputusan, yaitu di bidang perkebunan. PT Hanuraba Sawit Kencana merupakan perusahaan yang bergerak di bidang perkebunan kelapa sawit yang berada di Desa Manggar Jaya Kecamatan Tanjung Lago Kabupaten Banyuasin, Sumatera Selatan. PT Hanuraba Sawit Kencana berawal dari pendirian pabrik perkebunan kelapa sawit pada tahun 2015 di Banyuasin, Sumatera
Selatan. Kegiatan utama perusahaan ini meliputi pengelolaan kebun inti dan plasma berikut Pabrik Minyak Sawit (PMS), dengan produk utama minyak sawit dan inti sawit. Permasalahan yang dihadapi oleh pihak perusahaan PT Hanuraba Sawit Kencana dalam menentukan pengangkatan karyawan kontrak menjadi karyawan tetap yaitu sulitnya dalam proses penilaian yang objektif terhadap calon karyawan tetap PT. Hanuraba Sawit Kencana.

Pada saat ini PT. Hanuraba Sawit Kencana telah menetapkan kriteria-kriteria yang digunakan untuk melakukan penilaian kepada calon karyawan tetap. Kriteria-kriteria yang digunakan, yaitu: dorongan dan ketahanan, fleksibilitas dan kreativitas, jumlah pekerjaan, kecerdasan emosi, kerjasama, kesadaran finansial, komitmen dan loyalitas, komunikasi, kualitas pekerjaan, pelayanan pelanggan, pengetahuan akan pekerjaan, penyelesaian masalah, perencanaan dan pelaksanaan, perilaku etis, sensitivitas budaya dan organisasi, sikap belajar dan pengembangan diri. Prosedur yang saat ini digunakan yaitu Human Resource Development (HRD) menyeleksi calon karyawan tetap dengan cara mengambil calon-calon yang memenuhi kriteriakriteria yang telah ditentukan oleh perusahaan. Sehingga nantinya akan terpilih calon-calon karyawan tetap yang layak untuk melanjutkan tahap selanjutnya yaitu tahap pengangkatan. Pada tahap selanjutnya, HRD akan merekomendasikan caloncalon karyawan tetap terpilih kepada atasan mereka masing-masing untuk dinilai kinerjanya. Hasil penilaian masing-masing atasan kemudian akan diverifikasi oleh $H R D$ untuk kemudian disampaikan kepada senior asisten manajer perusahaan untuk menyetujui hasil karyawan yang sudah layak tersebut untuk menjadi karyawan tetap. Permasalahan lain yang muncul, yaitu perhitungan hasil penilaian dari masing-masing atasan masih dilakukan secara konvensional. Perhitungan dilakukan dengan mencari rata-rata nilai dari setiap calon karyawan tetap. Perhitungan yang hanya menggunakan rata-rata seperti ini berpotensi untuk dilakukan penilaian yang tidak objektif, dikarenakan seluruh kriteria menggunakan ketentuan dimana semakin tinggi penilaian maka semakin baik. Hal ini seharusnya dapat ditambahkan kriteria-kriteria yang lain seperti masa kerja, pendidikan, usia, jenis pelanggaran yang pernah dilakukan agar pemberian nilai lebih objektif.

Berdasarkan permasalahan tersebut, maka perlu adanya pemecahan masalah. Dalam penelitian ini dipilih penyelesaian masalah dengan cara menerapkan suatu metode pengambilan keputusan. Metode yang digunakan dalam penelitian ini yaitu Technique for Order Preference by Similarity to Ideal Solution (TOPSIS). Metode ini memiliki kehandalan karena mempertimbangkan jarak terpendek pada solusi ideal positif dan juga jarak terpanjang pada solusi ideal negatif. Menurut [3], menyebutkan 
bahwa metode Multi Attribute Decision Making (MADM) yang dalam hal ini digunakan metode TOPSIS telah gunakan secara luas, kemudahan dalam pemahaman metode, dan handal digunakan untuk mengukur kinerja relatif dari alternatif-alternatif yang ada dalam bentuk perhitungan matematis yang sederhana. Dan juga menurut [4], bahwa metode TOPSIS merupakan metode penyeimbang, dimana hasil buruk dalam satu kriteria dapat diseimbangkan dengan hasil baik dalam kriteria lainnya.

Kemudian juga digunakan beberapa referensi sebagai sumber pustaka untuk lebih mendukung penelitian ini. Pada penelitian [5] menggunakan metode TOPSIS terhadap sistem pendukung keputusan penerimaan pegawai. Beberapa kriteria yang digunakan, yaitu: nilai IPK, nilai TOEFL, pengalaman kerja, usia, dan Tes Potensi Akademik (TPA). Hasil pengujian dapat disimpulkan bahwa Sistem Pendukung Keputusan (SPK) penerimaan pegawai dengan metode TOPSIS menghasilkan sistem yang dapat memberikan rekomendasi pelamar terbaik sesuai dengan kriteria yang ditentukan.

Pada penelitian [6], menggunakan metode TOPSIS dalam penentuan dosen terbaik. Di dalam penelitian dijelaskan bahwa dalam hal pemberian penghargaan terhadap kinerja yang telah dilakukan sangat penting sebagai bentuk menghargai kinerja yang telah dilakukan. Para dosen yang merupakan komponen utama dalam menghasilkan lulusan dari masing-masing institusi pendidikan yang bersangkutan. Pemberian penghargaan terhadap dosen terbaik ini dapat menjadi salah satu cara untuk terus meningkatkan kualitas dosen dalam suatu instansi. Terdapat beberapa kriteria penilaian, yaitu: 1) Lama Kerja (K1), 2) Prestasi (K2), 3) Pengajaran (K3), 4) Penelitian (K4), 5) Pengabdian Masyarakat (K5). Kemudian untuk menentukan bobot masingmasing kriteria peneliti bekerja sama dengan staf Satuan Penjamin Mutu (SPM). Masing-masing kriteria ditentukan bobot dengan ketentuan, yaitu: K1 $=10, \mathrm{~K} 2=20, \mathrm{~K} 3=30, \mathrm{~K} 4=25, \mathrm{~K} 5=15$. Hasil dari penelitian ini yaitu 6 (enam) orang dosen terpilih untuk menjadi alternatif dosen terbaik. Dari hasil tersebut kriteria yang sangat mempengaruhi adalah jumlah penelitian dan rangking pengajaran, sedangkan lama kerja tidak begitu mempengaruhi.

Selanjutnya pada penelitian [7], menjelaskan permasalahan yang terjadi bahwa proses seleksi yang baik perlu dilakukan untuk mendapatkan calon pegawai yang sesuai dengan kriteria. Demikian pula pada proses rekrutmen relawan tenaga pengajar di Yayasan Istana Belajar Anak Banten (ISBANBAN). Terdapat beberapa kriteria yang digunakan, yaitu: 1) Kesiapan mengabdi selama 1 tahun (C1), 2) Leadership (C2), 3) Pendekatan terhadap anak (C3), 4) Karakter pribadi (C4). Kemudian penerapan metode TOPSIS diujikan kepada 5 (lima) calon relawan. Selanjutnya penentuan bobot kriteria dengan ketentuan sebagai berikut: $\mathrm{C} 1=0.4, \mathrm{C} 2=0.15, \mathrm{C} 3=$ $0.15, \mathrm{C} 4=0.3$. Hasil akhir pada penelitian ini adalah urutan prioritas nama-nama calon relawan, dengan total nilai yang tertinggi yang akan dipilih.

Pada penelitian [8] permasalahan yang terjadi bahwa alumni SMA sederajat seringkali mengalami kesulitan di dalam menentukan perguruan tinggi untuk melanjutkan studi. Pemilihan perguruan tinggi untuk alumni SMA sederajat terkendala hanya berdasarkan pendapat orang lain saja, bahkan sering kali karena mengikuti teman. Hal ini dikarenakan begitu banyak macam kriteria dari perguruan tinggi yang akhirnya membuat calon mahasiswa menjadi bingung dan memilih tanpa pertimbangan. Pemilihan perguruan tinggi seharusnya disesuaikan antara kriteria perguruan tinggi dengan kebutuhan dan kemampuan dari calon mahasiswa. Terdapat 7 (tujuh) kriteria yang digunakan, yaitu: 1) Biaya (BY), 2) Nilai Akreditasi (NA), 3) Prestasi (PS), 4) Pendidikan Dosen (PD), 5) Fasilitas (FS), 6) Beasiswa (BS), 7) UKM (UK). Selanjutnya untuk penentuan bobot kriteria digunakan dengan ketentuan sebagai berikut: $\mathrm{BY}=4, \mathrm{NA}=5, \mathrm{PS}=4, \mathrm{PD}=3, \mathrm{FS}=4, \mathrm{BS}=3$, UK $=3$. Hasil akhir dari penelitian ini adalah urutan prioritas perguruan tinggi dari nilai total tertinggi hingga terendah.

Pada penelitian [9], yang menggunakan metode TOPSIS untuk mendukung penentuan keluarga miskin pada desa Panca Karsa II. Terdapat 14 (empat belas) kriteria. Penelitian ini dilakukan untuk membantu pemerintah dalam program bantuan terhadap keluarga miskin. Selanjutnya pada penelitian [10], metode TOPSIS digunakan untuk membantu dalam penilaian kinerja karyawan. Digunakan 14 (empat belas) kriteria untuk menentukan alternatif terbaik yang terpilih. Sedangkan [11] menerapkan SPK untuk penentuan penerima bantuan $\mathrm{PKH}$.

\section{METODE PENELITIAN}

\subsection{Tahapan Penelitian}

Beberapa urutan tahapan yang dilakukan pada penelitian ini dapat dilihat pada Gambar 1.

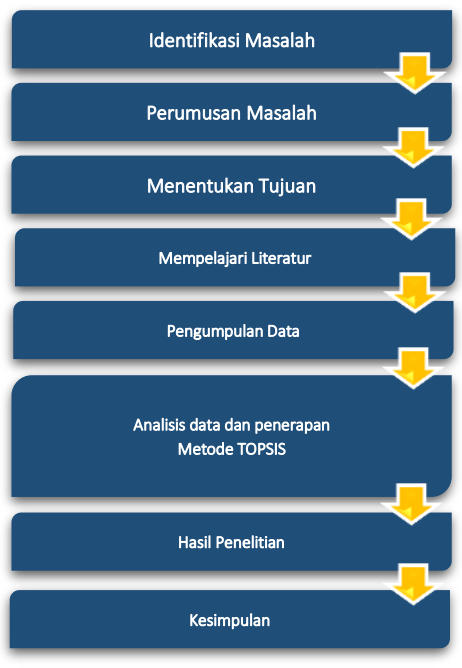

Gambar 1. Tahapan Penelitian 


\section{a) Identifikasi Masalah}

Tahap identifikasi masalah perlu dilakukan dalam hal ini untuk mengetahui permasalahan yang terjadi pada tempat penelitian. Pada penelitian ini, dilakukan identifikasi masalah dengan menanyakan langsung kepada staff yang bertanggungjawab dalam hal pengangkatan pegawai kontrak.

\section{b) Perumusan Masalah}

Metode deskriptif digunakan pada penelitian ini. Dengan metode ini, menjelaskan bahwa untuk memperoleh gambaran yang jelas mengenai masalah maka perlu dilakukan pengumpulan data, penyusunan data, dan pengelompokkan data.

c) Menentukan Tujuan

Tujuan pada penelitian ini adalah penerapan metode TOPSIS untuk pengangkatan karyawan kontrak menjadi karyawan tetap (studi kasus: PT Hanuraba Sawit Kencana).

\section{d) Pengumpulan Data}

Metode pengumpulan data dilakukan dengan cara melakukan pengamatan langsung di PT Hanuraba Sawit Kencana. Selain pengamatan, juga dilakukan wawancara kepada pihak-pihak yang terkait dengan penelitian ini. Selain itu, peneliti mengambil data-data yang dibutuhkan dalam penelitian ini. Data-data yang dibutuhkan misalnya, data-data karyawan kontrak yang akan diangkat sebagai karyawan tetap, kriteria-kriteria penilaian yang digunakan untuk menilai caloncalon karyawan tetap di perusahaan tersebut.

e) Analisis data dan penerapan Metode TOPSIS Pada tahap ini data yang telah dikumpulkan akan dianalisis. Kriteria-kriteria penilaian yang telah didapatkan kemudian ditentukan bobot dari masing-masing kriteria yang ada. Penentuan bobot dari masing-masing kriteria ditentukan langsung oleh pengambil keputusan, dalam hal ini adalah senior asisten manajer perusahaan. Setelah bobot ditentukan untuk masing-masing kriteria maka hal selanjutnya adalah menerapkan metode Technique for Order Preference by Similarity to Ideal Solution (TOPSIS). Secara umum, prosedur TOPSIS mengikuti langkah-langkah sebagai berikut:

1) Membuat matriks keputusan yang ternormalisasi.

2) Membuat matriks keputusan yang ternormalisasi terbobot.

3) Menentukan matriks solusi ideal positif dan matriks solusi ideal negatif.

4) Menentukan jarak antara nilai setiap alternatif dengan matriks solusi ideal positif dan matriks ideal negatif.

5) Menentukan nilai preferensi untuk setiap alternatif.

\section{f) Hasil Penelitian}

Analisis data dan penerapan metode TOPSIS yang telah dilakukan pada tahap sebelumnya akan diterapkan pada data sesungguhnya. Masukkan dan rekomendasi dari perusahaan dicatat dan digunakan untuk melakukan perbaikan penelitian ini.

g) Kesimpulan

Dari hasil penerapan metode TOPSIS diperoleh kesimpulan tentang sejauh mana penelitian memberikan kontribusi terhadap perusahaan. Saran-saran yang diberikan sebagai bahan masukkan akan ditampung untuk meningkatkan penelitian ini kedepannya.

\subsection{Rancangan Pengambilan Keputusan dengan Metode TOPSIS}

Langkah-langkah pada metode TOPSIS kemudian dituangkan dalam suatu diagram untuk mempermudah dalam pembacaan setiap langkah. Dapat dilihat pada Gambar 2.

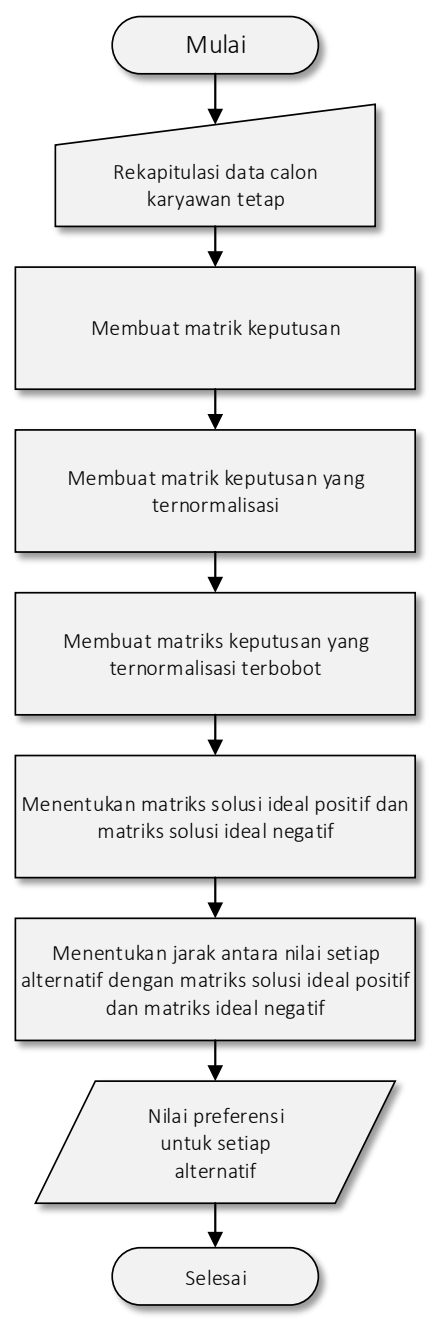

Gambar 2. Pengambilan Keputusan Dengan Metode TOPSIS

\subsection{Rancangan Proses Bisnis Pengangkatan Karyawan Kontrak dengan Menggunakan Metode TOPSIS}

Pada penelitian ini dirancang proses bisnis yang dapat dimanfaatkan oleh PT Hanuraba Sawit Kencana. Rancangan proses bisnis ini nantinya 
merupakan rekomendasi dalam penerapan metode TOPSIS. Dapat dilihat pada Gambar 3.

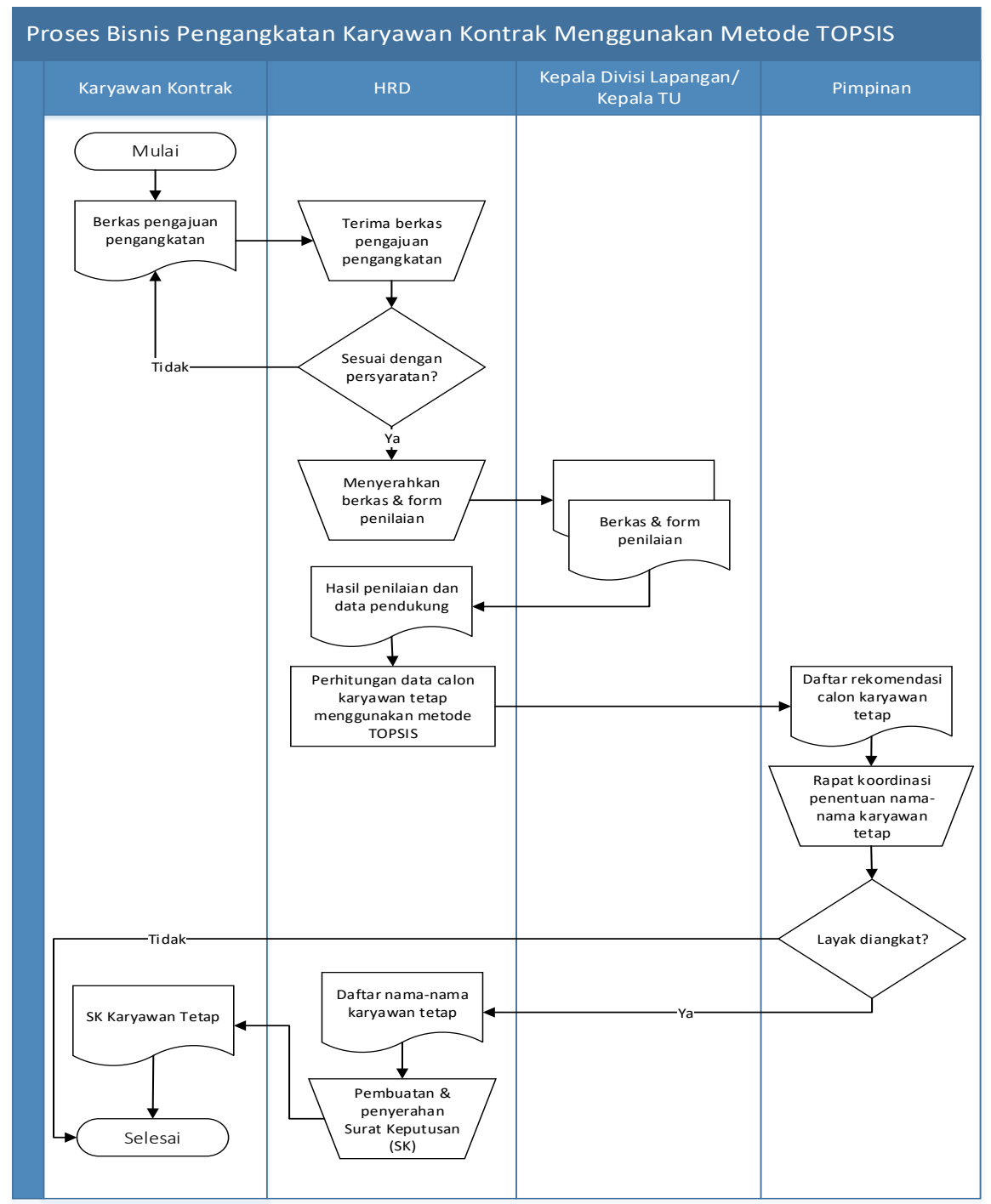

Gambar 3. Rancangan Proses Bisnis Dalam Penerapan Metode TOPSIS

\section{HASIL DAN PEMBAHASAN}

\subsection{Kriteria-kriteria yang Digunakan Dalam Penelitian}

Pada saat ini PT. Hanuraba Sawit Kencana telah menetapkan kriteria-kriteria yang digunakan untuk melakukan penilaian kepada calon karyawan tetap. Selain itu, pada penelitian ini ditambahkan beberapa kriteria lain agar penerapan metode TOPSIS ini menjadi lebih objektif. Dapat dilihat pada Tabel 1.

Tabel 1. Kriteria-kriteria yang Digunakan

\begin{tabular}{|c|c|c|c|c|}
\hline No. & Kriteria & Deskripsi & Bobot & Keterangan \\
\hline 1. & $\begin{array}{l}\text { Dorongan dan } \\
\text { Ketahanan (K1) }\end{array}$ & $\begin{array}{l}\text { Mendorong diri sendiri untuk mencapai hasil yang berkualitas dengan cara } \\
\text { tepat dan efisien dalam kurun waktu yang diberikan, merespon secara cepat } \\
\text { terhadap situasi yang berubah-ubah dan lebih berinisiatif untuk memulai } \\
\text { daripada menerima secara pasif. }\end{array}$ & 1 & $\begin{array}{c}\text { Kriteria dari } \\
\text { perusahaan }\end{array}$ \\
\hline 2. & $\begin{array}{l}\text { Fleksibilitas dan } \\
\text { Kreativitas (K2) }\end{array}$ & $\begin{array}{l}\text { Berpikir terbuka dan dapat beradaptasi dengan perubahan, mempertanyakan } \\
\text { pemikiran yang tradisional dan konvensional dan berupaya untuk } \\
\text { memperbaharui proses kerja untuk mencapai hasil yang maksimal. }\end{array}$ & 2 & $\begin{array}{c}\text { Kriteria dari } \\
\text { perusahaan }\end{array}$ \\
\hline 3. & $\begin{array}{l}\text { Jumlah Pekerjaan } \\
\text { (K3) }\end{array}$ & $\begin{array}{l}\text { Menyelesaikan seluruh pekerjaan yang berada dibawah tanggungjawabnya } \\
\text { secara efisien dan tepat waktu. }\end{array}$ & 3 & $\begin{array}{l}\text { Kriteria dari } \\
\text { perusahaan }\end{array}$ \\
\hline 4. & $\begin{array}{l}\text { Kecerdasan Emosi } \\
\text { (K4) }\end{array}$ & $\begin{array}{l}\text { Kemampuan menjaga keseimbangan yang positif untuk terus melakukan dan } \\
\text { memberikan hasil kerja dibawah tekanan tanpa menunjukkan sikap impulsif } \\
\text { yang dapat mempengaruhi masyarakat dan lingkungan. }\end{array}$ & 2 & $\begin{array}{c}\text { Kriteria dari } \\
\text { perusahaan }\end{array}$ \\
\hline
\end{tabular}




\begin{tabular}{|c|c|c|c|c|}
\hline No. & Kriteria & Deskripsi & Bobot & Keterangan \\
\hline 5. & Kerjasama (K5) & $\begin{array}{l}\text { Seorang anggota tim yang kooperatif dan partisipan, mau berkonsultasi untuk } \\
\text { belajar, menghormati orang lain, mendukung keputusan mayoritas dan } \\
\text { bijaksana serta memiliki sensivitas ketika berhubungan dengan orang lain } \\
\text { namun tetap menjaga pandangan independen dan objektif. }\end{array}$ & 4 & $\begin{array}{l}\text { Kriteria dari } \\
\text { perusahaan }\end{array}$ \\
\hline 6. & $\begin{array}{l}\text { Kesadaran } \\
\text { Finansial (K6) }\end{array}$ & $\begin{array}{l}\text { Kemampuan untuk mengevaluasi secara efektif dampak finansial dari setiap } \\
\text { tindakan melalui analisa pengeluaran dan keuntungan untuk mendapatkan } \\
\text { keputusan yang menguntungkan bagi perusahaan. }\end{array}$ & 1 & $\begin{array}{l}\text { Kriteria dari } \\
\text { perusahaan }\end{array}$ \\
\hline 7. & $\begin{array}{l}\text { Komitmen dan } \\
\text { Loyalitas (K7) }\end{array}$ & $\begin{array}{l}\text { Memiliki rasa kepemilikan dan akuntabilitas terhadap pekerjaan, berani } \\
\text { menanggung konsekuensi dari tindakan yang dilakukan, menerima dan } \\
\text { melakukan pekerjaan dengan standar yang diminta. }\end{array}$ & 4 & $\begin{array}{l}\text { Kriteria dari } \\
\text { perusahaan }\end{array}$ \\
\hline 8. & Komunikasi (K8) & $\begin{array}{l}\text { Menyampaikan ide dan informasi secara efektif, menunjukkan empati dan } \\
\text { berusaha untuk memahami orang lain. }\end{array}$ & 2 & $\begin{array}{l}\text { Kriteria dari } \\
\text { perusahaan }\end{array}$ \\
\hline 9. & $\begin{array}{l}\text { Kualitas } \\
\text { Pekerjaan (K9) }\end{array}$ & $\begin{array}{l}\text { Menjalankan tugas secara menyeluruh, memberikan perhatian yang detail dan } \\
\text { menindaklanjuti sampai standar yang diminta terpenuhi. }\end{array}$ & 5 & $\begin{array}{l}\text { Kriteria dari } \\
\text { perusahaan }\end{array}$ \\
\hline 10. & $\begin{array}{l}\text { Pelayanan } \\
\text { Pelanggan (K10) }\end{array}$ & $\begin{array}{l}\text { Memahami perspektif pelanggan internal dan eksternal, mengantisipasi dan } \\
\text { memenuhi kebutuhan mereka, santun dan bertindak secara profesional. }\end{array}$ & 4 & $\begin{array}{l}\text { Kriteria dari } \\
\text { perusahaan }\end{array}$ \\
\hline 11. & $\begin{array}{l}\text { Pengetahuan Akan } \\
\text { Pekerjaan (K11) }\end{array}$ & $\begin{array}{l}\text { Efektif mengaplikasikan pengetahuan yang dimiliki mengenai metode, teknik } \\
\text { dan keterampilan dalam lingkup fungsi yang spesifik. }\end{array}$ & 4 & $\begin{array}{l}\text { Kriteria dari } \\
\text { perusahaan }\end{array}$ \\
\hline 12. & $\begin{array}{l}\text { Penyelesaian } \\
\text { Masalah (K12) }\end{array}$ & $\begin{array}{l}\text { Lengkap dalam mengumpulkan informasi yang relevan, mampu menganalisa } \\
\text { data, berpikir menyeluruh dan sampai keputusan dan tindakan yang logis dan } \\
\text { masuk akal. }\end{array}$ & 3 & $\begin{array}{l}\text { Kriteria dari } \\
\text { perusahaan }\end{array}$ \\
\hline 13. & $\begin{array}{l}\text { Perencanaan dan } \\
\text { Pelaksanaan (K13) }\end{array}$ & $\begin{array}{l}\text { Efektif dalam membuat tujuan dan jadwal, memprioritaskan dan membagi } \\
\text { pekerjaan kedalam tugas- tugas yang dapat dikelola, berkoordinasi dengan } \\
\text { semua pihak yang terkait. }\end{array}$ & 2 & $\begin{array}{l}\text { Kriteria dari } \\
\text { perusahaan }\end{array}$ \\
\hline 14. & $\begin{array}{l}\text { Perilaku Etis } \\
\text { (K14) }\end{array}$ & $\begin{array}{l}\text { Menghormati dan bertindak sesuai dengan nilai dan peraturan perusahaan, } \\
\text { menunjukkan kejujuran dan menjaga komitmen, memperlakukan orang lain } \\
\text { dengan hormat dan adil. }\end{array}$ & 3 & $\begin{array}{l}\text { Kriteria dari } \\
\text { perusahaan }\end{array}$ \\
\hline 15. & $\begin{array}{l}\text { Sensivitas Budaya } \\
\text { dan Organisasi } \\
\text { (K15) }\end{array}$ & $\begin{array}{l}\text { Menampilkan pola pikir yang terbuka, memahami dan menghormati perbedaan } \\
\text { budaya dan pandangan orang lain dan menunjukkan kemampuan untuk } \\
\text { berkontribusi. }\end{array}$ & 1 & $\begin{array}{l}\text { Kriteria dari } \\
\text { perusahaan }\end{array}$ \\
\hline 16. & $\begin{array}{l}\text { Sikap Belajar dan } \\
\text { Pengembangan } \\
\text { Diri (K16) }\end{array}$ & $\begin{array}{l}\text { Mencari kesempatan untuk belajar dan mengaplikasikan pengetahuan baru } \\
\text { untuk meningkatkan pengetahuan. }\end{array}$ & 2 & $\begin{array}{l}\text { Kriteria dari } \\
\text { perusahaan }\end{array}$ \\
\hline 17. & Masa Kerja (K17) & $\begin{array}{l}\text { Jumlah masa kerja karyawan dihitung dari tanggal mulai melaksanakan tugas } \\
\text { dan tidak pernah terputus kontrak. }\end{array}$ & 5 & $\begin{array}{c}\text { Kriteria } \\
\text { penambahan }\end{array}$ \\
\hline 18. & Pendidikan (K18) & Pendidikan terakhir calon karyawan tetap. & 3 & $\begin{array}{c}\text { Kriteria } \\
\text { penambahan }\end{array}$ \\
\hline 19. & Usia (K19) & Usia calon karyawan tetap dihitung dari tanggal lahir. & 4 & $\begin{array}{l}\text { Kriteria } \\
\text { penambahan }\end{array}$ \\
\hline 20. & $\begin{array}{l}\text { Jenis Pelanggaran } \\
\text { yang Pernah } \\
\text { Dilakukan (K20) }\end{array}$ & $\begin{array}{l}\text { Banyaknya pelanggaran yang pernah dilakukan calon karyawan tetap dihitung } \\
\text { dari mulai melaksanakan tugas. }\end{array}$ & 5 & $\begin{array}{c}\text { Kriteria } \\
\text { penambahan }\end{array}$ \\
\hline
\end{tabular}

Pada penelitian ini ditentukan bobot untuk masing-masing kriteria yang digunakan dalam penelitian ini. Bobot kriteria ditentukan berdasarkan diskusi dan konsultasi dengan pengambil keputusan (pihak pimpinan). Dalam hal ini digunakan skala 1 (satu) hingga 5 (lima) untuk menentukan bobot, yaitu: 1 = Sangat rendah, 2 = Rendah, 3 = Cukup, $4=$ Tinggi, $5=$ Sangat Tinggi.

\subsection{Detail Data Alternatif Kriteria}

Pada penelitian ini digunakan 20 (dua puluh) kriteria dengan masing-masing data alternatif. Data kriteria pada proses pengangkatan karyawan kontrak, dapat dilihat pada Tabel 2.

Tabel 2. Data Alternatif Kriteria

\begin{tabular}{cll}
\hline No. & \multicolumn{1}{c}{ Kriteria } & Data Alternatif Kriteria \\
\hline 1. & Dorongan dan Ketahanan (K1) & Data numerik. \\
2. & Fleksibilitas dan Kreativitas (K2) & Data Numerik. \\
3. & Jumlah Pekerjaan (K3) & Data Numerik. \\
4. & Kecerdasan Emosi (K4) & Data Numerik. \\
5. & Kerjasama (K5) & Data Numerik. \\
6. & Kesadaran Finansial (K6) & Data Numerik. \\
7. & Komitmen dan Loyalitas (K7) & Data Numerik. \\
8. & Komunikasi (K8) & Data Numerik. \\
9. & Kualitas Pekerjaan (K9) & Data Numerik. \\
10. & Pelayanan Pelanggan (K10) & Data Numerik. \\
11. & Pengetahuan Akan Pekerjaan (K11) & Data Numerik. \\
12. & Penyelesaian Masalah (K12) & Data Numerik. \\
13. & Perencanaan dan Pelaksanaan (K13) & Data Numerik. \\
14. & Perilaku Etis (K14) & Data Numerik. \\
15. & Sensivitas Budaya dan Organisasi & Data Numerik. \\
& (K15) &
\end{tabular}




\begin{tabular}{cll}
\hline No. & \multicolumn{1}{c}{ Kriteria } & Data Alternatif Kriteria \\
\hline 16. & Sikap Belajar dan Pengembangan & Data Numerik. \\
& Diri (K16) & \\
17. & Masa Kerja (K17) & Data Numerik. \\
18. & Pendidikan (K18) & SD/MI \\
& & SLTP/SMP/MTs \\
& & SLTA/SMA/SMK/MA \\
& & D-I \\
& & D-III \\
19. & Usia (K19) & D-VI/S-1 \\
20. & Jenis Pelanggaran yang Pernah & Data Numerik. \\
& Dilakukan (K20) & Tidak Ada \\
& & Ringan \\
& & Sedang \\
\hline
\end{tabular}

Pada kriteria Jenis Pelanggaran yang Pernah dilakukan (K20), jenis pelanggaran secara detail mengikuti kebijakan yang telah ditentukan oleh perusahaan sesuai jenis pelanggarannya.

\subsection{Penerapan Metode Technique for Order Preference by Similarity to Ideal Solution (TOPSIS)}

Pada penelitian ini, penerapan metode TOPSIS diimplementasikan hanya untuk seluruh karyawan yang berstatus "Karyawan harian lepas" yang kemudian ingin diangkat menjadi "Karyawan harian tetap". Dari data karyawan yang berjumlah 615 orang, terdapat 490 orang yang masih berstatus "Karyawan harian lepas ". Data karyawan sebanyak 490 orang inilah yang akan diterapkan menggunakan metode TOPSIS. Data karyawan berstatus "Karyawan harian lepas" dapat dilihat pada Tabel 3.

Tabel 3. Data Karyawan Yang Berstatus Harian Lepas

\begin{tabular}{|c|c|c|c|c|c|c|c|c|c|c|c|c|c|c|c|c|c|c|c|c|c|}
\hline \multirow{3}{*}{ No. } & \multirow{3}{*}{$\begin{array}{c}\text { ALTERNAT } \\
\text { IF }\end{array}$} & \multicolumn{20}{|c|}{ Kriteria } \\
\hline & & K1 & K2 & K3 & K4 & K5 & K6 & $\begin{array}{c}K \\
7\end{array}$ & K8 & K9 & $\begin{array}{l}K \\
10\end{array}$ & $\begin{array}{l}\mathrm{K} \\
\mathbf{1 1}\end{array}$ & $\begin{array}{l}K \\
12\end{array}$ & $\begin{array}{l}K \\
13\end{array}$ & $\begin{array}{l}K \\
14\end{array}$ & $\begin{array}{l}K \\
15\end{array}$ & $\begin{array}{l}K \\
16\end{array}$ & $\begin{array}{l}\mathrm{K} \\
\mathbf{1 7}\end{array}$ & $\begin{array}{l}K \\
18\end{array}$ & $\begin{array}{l}K \\
19\end{array}$ & $\begin{array}{l}\mathbf{K} \\
\mathbf{2 0}\end{array}$ \\
\hline & & B & B & B & B & B & B & B & B & B & B & B & B & B & B & B & $\mathbf{B}$ & B & B & $\mathbf{C}$ & C \\
\hline 1 & Nursiah & 5 & 8 & 7 & 9 & 9 & 7 & 9 & 7 & 9 & 6 & 8 & 9 & 9 & 6 & 7 & 7 & 3.30 & $\begin{array}{c}\text { SLT } \\
\mathrm{P}\end{array}$ & 37.41 & $\begin{array}{c}\text { Tidak } \\
\text { Ada }\end{array}$ \\
\hline 2 & $\begin{array}{l}\text { Ahmad } \\
\text { susanto }\end{array}$ & 9 & 7 & 6 & 5 & 7 & 8 & 5 & 8 & 5 & 9 & 8 & 5 & 8 & 7 & 8 & 9 & 3.50 & $\begin{array}{c}\text { SLT } \\
\text { A }\end{array}$ & 26.69 & $\begin{array}{c}\text { Tidak } \\
\text { Ada }\end{array}$ \\
\hline 3 & Meri maryati & 9 & 7 & 7 & 7 & 9 & 5 & 5 & 8 & 5 & 5 & 5 & 9 & 7 & 7 & 5 & 5 & 3.40 & $\begin{array}{c}\text { SLT } \\
\text { A }\end{array}$ & 38.50 & $\begin{array}{c}\text { Tidak } \\
\text { Ada }\end{array}$ \\
\hline 4 & Suratun & 7 & 6 & 7 & 5 & 8 & 6 & 6 & 6 & 5 & 7 & 6 & 9 & 9 & 5 & 9 & 8 & 6.53 & SD & 34.61 & $\begin{array}{c}\text { Tidak } \\
\text { Ada }\end{array}$ \\
\hline 5 & Roslindah & 6 & 7 & 9 & 6 & 7 & 6 & 9 & 7 & 9 & 9 & 5 & 7 & 9 & 8 & 6 & 9 & 3.19 & $\begin{array}{c}\text { SLT } \\
\text { A }\end{array}$ & 33.38 & $\begin{array}{c}\text { Tidak } \\
\text { Ada }\end{array}$ \\
\hline 6 & Suparni & 6 & 5 & 7 & 8 & 5 & 5 & 6 & 7 & 7 & 7 & 5 & 8 & 7 & 9 & 5 & 6 & 6.49 & SD & 44.86 & $\begin{array}{c}\text { Tidak } \\
\text { Ada }\end{array}$ \\
\hline 7 & Martanti & 9 & 6 & 7 & 6 & 5 & 7 & 9 & 9 & 9 & 6 & 6 & 8 & 8 & 7 & 6 & 9 & 6.74 & SD & 47.18 & $\begin{array}{c}\text { Tidak } \\
\text { Ada }\end{array}$ \\
\hline 8 & $\begin{array}{l}\text { Rajendra } \\
\text { purnama.w }\end{array}$ & 6 & 6 & 5 & 8 & 5 & 5 & 8 & 8 & 8 & 5 & 5 & 9 & 7 & 6 & 6 & 5 & 0.28 & $\begin{array}{c}\text { SLT } \\
\mathrm{P}\end{array}$ & 20.65 & $\begin{array}{c}\text { Tidak } \\
\text { Ada }\end{array}$ \\
\hline 9 & Hunaini & 8 & 9 & 6 & 8 & 7 & 9 & 8 & 5 & 6 & 8 & 6 & 7 & 5 & 6 & 8 & 6 & 1.66 & $\begin{array}{c}\text { SLT } \\
\text { A }\end{array}$ & 24.53 & $\begin{array}{c}\text { Tidak } \\
\text { Ada }\end{array}$ \\
\hline 10 & $\begin{array}{l}\text { Femiprihartin } \\
\text { i }\end{array}$ & 5 & 8 & 5 & 8 & 9 & 8 & 6 & 5 & 9 & 7 & 7 & 8 & 9 & 6 & 7 & 6 & 1.50 & $\begin{array}{c}\text { SLT } \\
\text { A }\end{array}$ & 19.90 & $\begin{array}{c}\text { Tidak } \\
\text { Ada }\end{array}$ \\
\hline 11 & $\begin{array}{l}\text { Abdul ahlim } \\
\text { tambunan }\end{array}$ & 7 & 8 & 8 & 9 & 7 & 7 & 9 & 9 & 6 & 6 & 5 & 5 & 9 & 6 & 5 & 7 & 1.41 & $\begin{array}{c}\text { SLT } \\
\text { A }\end{array}$ & 21.09 & $\begin{array}{c}\text { Tidak } \\
\text { Ada }\end{array}$ \\
\hline 12 & Agustin & 6 & 6 & 8 & 9 & 5 & 6 & 6 & 9 & 5 & 6 & 9 & 5 & 7 & 7 & 5 & 7 & 1.16 & SD & 49.43 & $\begin{array}{c}\text { Tidak } \\
\text { Ada }\end{array}$ \\
\hline 13 & M.saleng & 8 & 7 & 6 & 5 & 9 & 8 & 9 & 5 & 6 & 5 & 5 & 7 & 5 & 5 & 8 & 6 & 2.39 & $\begin{array}{l}\text { SLT } \\
\mathrm{P}\end{array}$ & 25.10 & $\begin{array}{c}\text { Tidak } \\
\text { Ada }\end{array}$ \\
\hline 14 & Dwi prasetyo & 8 & 5 & 9 & 9 & 5 & 8 & 9 & 6 & 7 & 5 & 8 & 9 & 8 & 5 & 6 & 9 & 2.39 & SD & 25.40 & $\begin{array}{c}\text { Tidak } \\
\text { Ada }\end{array}$ \\
\hline 15 & $\begin{array}{l}\text { Hendri } \\
\text { saputra }\end{array}$ & 8 & 9 & 6 & 9 & 5 & 5 & 5 & 8 & 9 & 6 & 9 & 8 & 5 & 7 & 8 & 9 & 2.36 & $\begin{array}{c}\text { SLT } \\
\mathrm{P}\end{array}$ & 22.66 & $\begin{array}{c}\text { Tidak } \\
\text { Ada }\end{array}$ \\
\hline 16 & $\begin{array}{l}\text { Ardianus } \\
\text { seran }\end{array}$ & 9 & 5 & 5 & 5 & 9 & 8 & 6 & 9 & 7 & 5 & 7 & 7 & 8 & 9 & 9 & 5 & 1.93 & SD & 36.68 & $\begin{array}{c}\text { Tidak } \\
\text { Ada }\end{array}$ \\
\hline
\end{tabular}




\begin{tabular}{|c|c|c|c|c|c|c|c|c|c|c|c|c|c|c|c|c|c|c|c|c|c|}
\hline \multirow{3}{*}{ No. } & \multirow{3}{*}{$\begin{array}{c}\text { ALTERNAT } \\
\text { IF }\end{array}$} & \multicolumn{20}{|c|}{ Kriteria } \\
\hline & & K1 & K2 & $\mathbf{K 3}$ & K4 & K5 & K6 & $\begin{array}{c}K \\
7\end{array}$ & K8 & K9 & $\begin{array}{c}K \\
10\end{array}$ & $\begin{array}{l}\mathrm{K} \\
\mathbf{1 1}\end{array}$ & $\begin{array}{l}K \\
12\end{array}$ & $\begin{array}{c}K \\
13\end{array}$ & $\begin{array}{c}K \\
14\end{array}$ & $\begin{array}{c}K \\
15\end{array}$ & $\begin{array}{c}K \\
16\end{array}$ & $\begin{array}{l}\text { K } \\
17\end{array}$ & $\begin{array}{l}K \\
18\end{array}$ & $\begin{array}{c}K \\
19\end{array}$ & $\begin{array}{l}\mathbf{K} \\
\mathbf{2 0}\end{array}$ \\
\hline & & B & B & B & B & B & B & B & B & B & B & B & B & B & B & B & B & B & B & C & C \\
\hline 17 & Dedi & 8 & 9 & 9 & 9 & 8 & 5 & 9 & 9 & 9 & 9 & 5 & 7 & 7 & 8 & 9 & 7 & 1.83 & SD & 36.81 & $\begin{array}{c}\text { Tidak } \\
\text { Ada }\end{array}$ \\
\hline 18 & Agus adri & 5 & 8 & 5 & 7 & 7 & 5 & 7 & 6 & 6 & 5 & 8 & 8 & 5 & 8 & 8 & 7 & 1.38 & $\mathrm{SD}$ & 20.46 & $\begin{array}{c}\text { Tidak } \\
\text { Ada }\end{array}$ \\
\hline 19 & $\begin{array}{l}\text { Ahmad } \\
\text { supriadi }\end{array}$ & 6 & 7 & 9 & 6 & 7 & 8 & 6 & 9 & 7 & 8 & 7 & 8 & 6 & 6 & 6 & 5 & 1.00 & $\begin{array}{c}\text { SLT } \\
\text { A }\end{array}$ & 25.81 & $\begin{array}{c}\text { Tidak } \\
\text { Ada }\end{array}$ \\
\hline 20 & Wardi & 8 & 5 & 9 & 6 & 9 & 7 & 8 & 6 & 8 & 7 & 7 & 5 & 6 & 5 & 9 & 6 & 0.91 & $\begin{array}{l}\text { SLT } \\
\mathrm{P}\end{array}$ & 31.41 & $\begin{array}{c}\text { Tidak } \\
\text { Ada }\end{array}$ \\
\hline$\ldots$ & & & & & & & & & & & & & & & & & & & & & \\
\hline$\cdots$ & & & & & & & & & & & & & & & & & & & & & \\
\hline 490 & $\begin{array}{l}\text { Didit } \\
\text { hermanto }\end{array}$ & 5 & 7 & 7 & 9 & 5 & 7 & 6 & 8 & 8 & 7 & 5 & 6 & 5 & 8 & 9 & 8 & 0.16 & $\begin{array}{l}\text { SLT } \\
\text { A }\end{array}$ & 18.03 & $\begin{array}{c}\text { Tidak } \\
\text { Ada }\end{array}$ \\
\hline
\end{tabular}

Keterangan:

Huruf B berarti Benefit, dan huruf C berarti Cost

Selanjutnya, dengan mengikuti langkahlangkah yang terdapat pada Gambar 2 maka dihasilkan alternatif terpilih yang selanjutnya diurutkan berdasarkan Kedekatan Relatif (Relative Closeness) untuk Setiap Alternatif $(\mathrm{Ci}+)$ dari yang tertinggi hingga ke rendah. Dapat dilihat pada Tabel 4.

Tabel 4. Hasil Akhir Perangkingan 10 Teratas

\begin{tabular}{|c|c|c|c|c|c|}
\hline No. & ALTERNATIF & JABATAN & DIVISI & $\begin{array}{c}\text { JENIS } \\
\text { KELAMIN }\end{array}$ & $\mathbf{C i}+$ \\
\hline 1 & Ekarius zalogo & Pemanen & Divisi-1 & Laki-laki & 0.9698039145 \\
\hline 2 & Harmonis laia & Pemanen & Divisi-3 & Laki-laki & 0.9673153803 \\
\hline 3 & Azis maelani & Pekerja rawat & Divisi-4 & Laki-laki & 0.9665500850 \\
\hline 4 & Jeri saputra & Pekerja rawat & Divisi-5 & Laki-laki & 0.9642884240 \\
\hline 5 & Sakka tang & Pekerja rawat & Divisi-3 & Laki-laki & 0.9636914824 \\
\hline 6 & Desi & Pekerja pupuk & Divisi-pupuk & Laki-laki & 0.9635225288 \\
\hline 7 & Muhammad azis & Pekerja rawat & Divisi-4 & Laki-laki & 0.9631280984 \\
\hline 8 & Judiko bancin & Pekerja rawat & Divisi-5 & Laki-laki & 0.9618254951 \\
\hline 9 & Puisi hati & Pemanen & Divisi-6 & Laki-laki & 0.9606065694 \\
\hline 10 & Didit hermanto & Helper mekanik & Workshop & Laki-laki & 0.9599639690 \\
\hline . & . & . & . & . & . \\
\hline . & . & . & . & . & . \\
\hline . & . & . & . & . & . \\
\hline 489 & Poniman & Pemanen & Divisi-2 & Laki-laki & 0.0921326006 \\
\hline 490 & Wan hasan & Pemanen & Divisi-3 & Laki-laki & 0.0230053179 \\
\hline
\end{tabular}

\section{KESIMPULAN}

Berdasarkan hasil penelitian dan pembahasan yang terkait dengan penerapan metode TOPSIS untuk pengangkatan karyawan kontrak menjadi karyawan tetap, maka diperoleh kesimpulan sebagai berikut:

1). Penggunaan kriteria-kriteria tambahan yang digunakan dalam penelitian ini, dapat memberikan penilaian yang lebih objektif. Perhitungan setiap kriteria tidak hanya bersifat benefit saja tetapi juga memasukkan kriteria yang bersifat cost.
2). Hasil akhir menampilkan urutan prioritas rekomendasi calon karyawan tetap yang memenuhi seluruh kriteria yang digunakan dalam penelitian ini. 3). Kriteria-kriteria seperti Kualitas Pekerjaan, Masa Kerja, Usia, dan Jenis Pelanggaran yang Pernah dilakukan memiliki pengaruh yang besar dalam penentuan calon karyawan tetap.

\section{DAFTAR PUSTAKA}

[1] M. K. Kusrini., 2007, Konsep dan Aplikasi Sistem Pendukung Keputusan. Graha Ilmu. Yogyakarta 
[2] H. Pratiwi, 2016, Buku Ajar Sistem Pendukung Keputusan. Deepublish.Yogyakarta

[3] M. Murnawan and A. F. Siddiq., 2012, "Sistem Pendukung Keputusan Menggunakan Metode Technique for Order by Similarity to Ideal Solution (TOPSIS)," J. Sist. Inf., vol. 4, no. 1, pp. 398-412.

[4] Z. Pavić and V. Novoselac., 2013,"Notes on TOPSIS Method," Int. J. Res. Eng. Sci., vol. 1, no. 2, pp. 5-12.

[5] E. G. Wahyuni and A. T. Anggoro., 2017, "Sistem Pendukung Keputusan Penerimaan Pegawai dengan Metode TOPSIS," Sains Teknol. dan Ind., vol. 14, no. 2, pp. 108-116.

[6] G. Wibisono, A. Amrulloh, and E. Ujianto., 2019,"Penerapan Metode TOPSIS Dalam Penentuan Dosen Terbaik," Ilk. J. Ilm., vol. 11, no. 2, pp. 102-109.

[7] H. T. Sigit and T. R. O. Friyansyah, 2019,"Sistem Seleksi Relawan Tenaga Pengajar Menggunakan Metode TOPSIS," JSiI, vol. 6, no. 2, pp. 86-91

[8] H. Hertyana., 2019,"Sistem Pendukung Keputusan Seleksi Pemilihan Perguruan Tinggi Menggunakan Metode TOPSIS," J. PILAR Nusa Mandiri, vol. 15, no. 1, pp. 97-102.

[9] I. Muzakkir., 2017,"Penerapan Metode Topsis Untuk Sistem Pendukung Keputusan Penentuan Keluarga Miskin Pada Desa Panca Karsa II," Ilk. J. Ilm., vol. 9, no. 3, pp. 274-281.

[10] N. Palasara and T. Baidawi., 2018, "Penerapan Metode TOPSIS Pada Peningkatan Kinerja Karyawan," J. Inform., vol. 5, no. 2, pp. 287294.

11 A. R. Laisouw, S. Lutfi dan F. Tempola., 2019. "Sistem Pendukung Keputusan Pemberian Bantuan Program Keluarga Harapan (PKH) pada Orang Miskin di Kota Ternate Menggunakan Metode AHP," JIKO (Jurnal Informatika dan Komputer), vol.2, no.1, pp.3440 